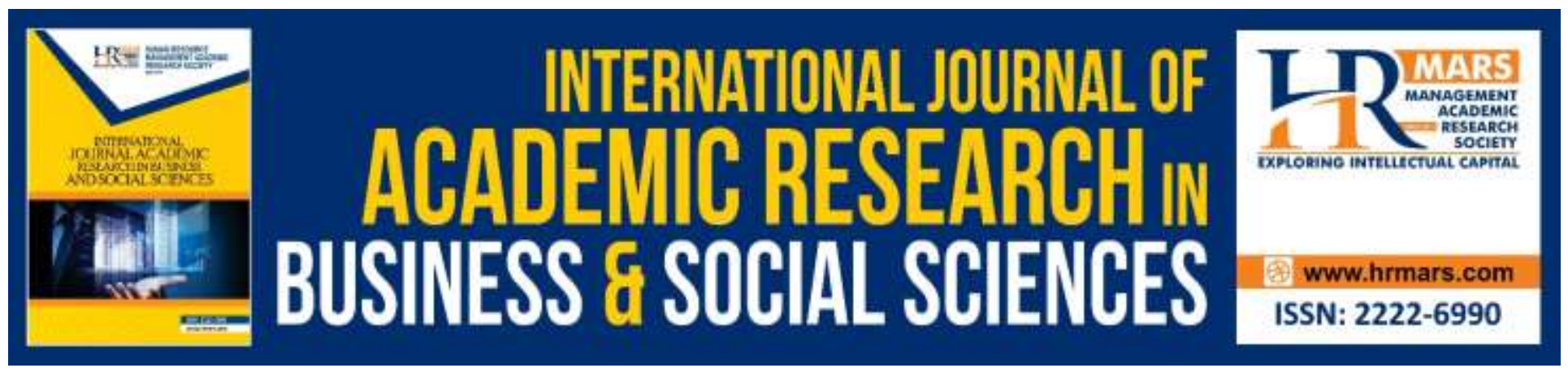

\title{
Item Analysis of Technology Challenges Among Adolescent Using Rasch Model
}

\author{
Salwana Mahamud, Norasmah Othman
}

To Link this Article: http://dx.doi.org/10.6007/IJARBSS/v9-i6/6229

DOI: $10.6007 /$ IJARBSS/v9-i6/6229

Received: 08 April 2019, Revised: 11 May 2019, Accepted: 02 June 2019

Published Online: 25 June 2019

In-Text Citation: (Mahamud \& Othman, 2019)

To Cite this Article: Mahamud, S., \& Othman, N. (2019). Item Analysis of Technology Challenges Among Adolescent Using Rasch Model. International Journal of Academic Research in Business and Social Sciences, 9(6), 1314-1326.

Copyright: (C) 2019 The Author(s)

Published by Human Resource Management Academic Research Society (www.hrmars.com)

This article is published under the Creative Commons Attribution (CC BY 4.0) license. Anyone may reproduce, distribute, translate and create derivative works of this article (for both commercial and non-commercial purposes), subject to full attribution to the original publication and authors. The full terms of this license may be seen

at: http://creativecommons.org/licences/by/4.0/legalcode

Vol. 9, No. 6, 2019, Pg. $1314-1326$

http://hrmars.com/index.php/pages/detail/IJARBSS

JOURNAL HOMEPAGE

Full Terms \& Conditions of access and use can be found at http://hrmars.com/index.php/pages/detail/publication-ethics 


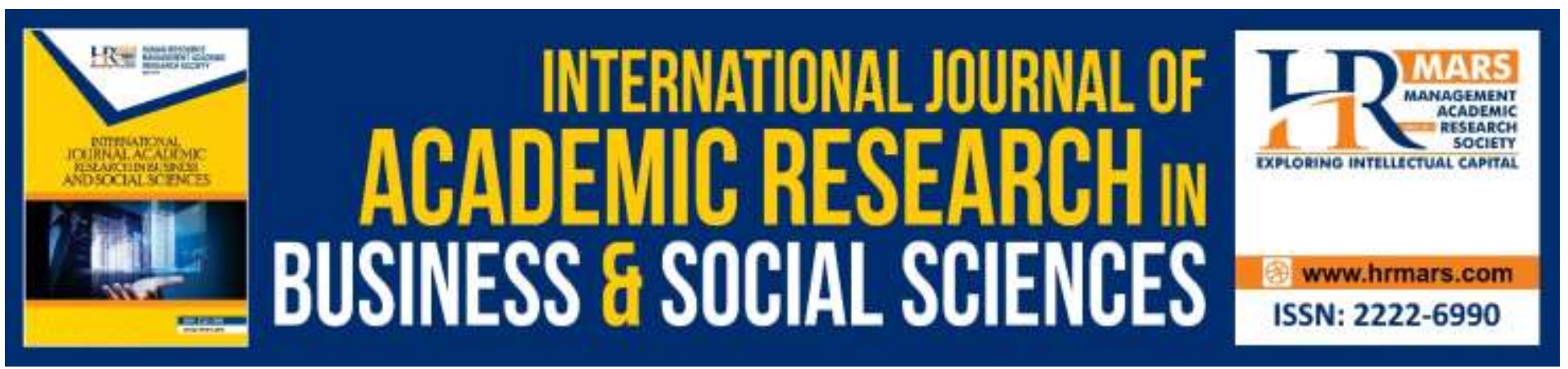

\title{
Item Analysis of Technology Challenges Among Adolescent Using Rasch Model
}

\author{
Salwana Mahamud, Norasmah Othman \\ Faculty of Education, National University of Malaysia (UKM)
}

\begin{abstract}
This scientific study is aimed at analyzing technology challenge items among adolescent. This study was a quantitative study using questionnaire as an instrument for collecting data. The Rasch model is used to identify the most important challenges among adolescent. A total of 175 samples comprising 15 to 18 years old from three types of school were selected. A total of 76 technology challenge items are listed based on the Youth Challenge Model consisting of six dimensions. The findings show that the main challenged among adolescent are in the dimensions of creativity and innovation with average of 0.188 logits, followed by the dimensions of information and communication technology (ICT) 0.174 logits and the science and technology dimensions of 0.170 logits. The implication of this study illustrates that further actions needs to be done by the stakeholder in planning for adolescent development programs to expand their potential to continue to meet increasingly challenges globally.
\end{abstract}

Keywords: Technology Challenge, adolescent, item analysis, Rasch Model, Technology Challenge Model.

\section{Introduction}

This study discusses technology challenges among adolescent. The Rasch Model is used to determine the technological challenges based on the Youth Challenge Model in the technology domain. This challenge coincides with the era of the Industrial Revolution 4.0 that has hit the world and has led to changes in the lifestyle of the community (Schwab, 2016). The world should respond to changes in integration and comprehensiveness by involving all level of society (Tjandrawinata, 2016). This technology speed creates a gap between existing skills and required skills in the future (Deloitte Global, 2018). Technology changes make a big difference to adolescent because their brain is adaptable (Giedd, 2012; Mak et al., 2014). A vast source of information requires adolescent to be more critical in evaluating information, synthesizing content and using it in solving problem. It is indirectly able to educate adolescent to be more independent in exploring knowledge in their own way. However, this skill is still dubious because there is a generation gap between students and teachers (Giedd, 2012). 
Internet popularity has increased rapidly among adolescent. In the United States, the use of smartphones among adolescence to access the internet is $74 \%$ (George \& Odger, 2015), and Iran is 90.3\% (Ghasemi et al., 2017). The study of Mak et al., (2014) reported that the frequency of internet usage more than three times a day among adolescent was $11.6 \%$ for China, $39.0 \%$ for Hong Kong, $32.8 \%$ for Japan, $12.8 \%$ for South Korea and $22.8 \%$ for the Philippines. In Malaysia, internet usage statistics are 76.9\% (Malaysian Communication and Multimedia Commission, 2017). Internet usage among adolescent aged 15 years to 19 years is $12.6 \%$ (Malaysian Communication and Multimedia Commission, 2017). Uncontrolled internet usage among adolescent will have adverse effects such as depression and deterioration of everyday life (Anderson et al., 2017).

The abundance of information in the virtual world that easily accessible through digital media is a challenge especially for adolescent. This is because adolescent are those who are undergoing transition to adulthood. Adolescent with the attitude of trying and exploring makes them susceptible to a negative thing (Utami, 2014, Maya, 2015). Furthermore, the use of new gadgets or technologies such as smartphones makes them very comfortable following the exposure of this technology when they were children (Ceobanu \& Boncu, 2014). The addiction to surfing the social media sites will indirectly create a negative culture because the information obtained is very broad and without filtering (Fauzi, 2017). This finding is also supported by Nordin et al., (2015) which stresses that technology is a factor that affects student misconduct. Adolescent need to be well educated so that they can act wisely assessing information obtained from various sources.

In fact, adolescent now face huge challenges of ICT technology development. This statement is supported by the finding of the previous study on the negative effects of ICT utilization which caused ICT addiction (Guan \& Subramanyam, 2009), involved in immoral acts and malicious behavior (Ismail et., 2012), as well as solitary (Ramli, 2011). This negative impact will lead to human capital development not feasible as intended in the statement of the Malaysian Youth Policy (Malaysian Ministry of Youth and Sports, 2017). Adolescent need to be prepared with mental and physical endurance to meet global challenges. Cases of abuse ICTs such as fraud, cyber threats, spam, intrusion, and the spread of viruses that damage the computer system (malware) show an increase (Malaysia Computer Emergency Response Team, 2017). The fraud cases recorded the highest cases of 3821 cases, followed by breach cases of 2011, and the spread of malware 814 cases and cyber threats 560 (Malaysian Computer Emergency Response Team, 2017).

In addition, cyber bullying cases that involve adolescent are also increasing. A total of $63.2 \%$ of 1382 adolescent aged 15 years to 30 years old were victims of cyber bullying (Institute For Youth Research Malaysia, 2017). More worrying when this cyber bullying cause negative effects on victims such as restlessness and depression. Even chronic it can cause suicide victims (Singh, 2013). These statistics show that adolescent have to face the challenges of technological advances.

\section{Research Objective}

Analyze technological challenge items in order to identify important challenge among adolescent using Rasch Model. 


\section{Methodology}

This study is quantitative study using survey method. The survey method is appropriate as it provides information on numerical data regarding trends or attitudes (Cresswell, 2017). This method is chosen accordance with the needs of researchers in analyzing the challenges or problems faced by adolescent in the technology era. The population of the study was the pupils of three types of schools namely National High School, Malaysia Islamic High School and Vocational College in the State of Selangor. Sample selection is strata of various stages, ie, the first level is bases on three types of school. Next, sample selection is based on the age group of 15 years, 16 years, 17 years and 18 years. The third stage involves the gender of male and female. A total of 200 people were selected as samples. After data cleaning was done. Only 175 sampel (87.5\%) were used as sample surveys. This amount coincides with the permissible range of $70 \%$ to $80 \%$ (Cohen et al., 2011). Table 1 shows the demographic profile of the sample survey.

Table 1

Demographic Profile Study Samples

\begin{tabular}{cccc}
\hline Variables & Description & Frequency & Percentage \\
\hline School Type & National High School Malaysia & 67 & $38.3 \%$ \\
& Islamic High School & 56 & $32.0 \%$ \\
& Vocational College & 52 & $29.7 \%$ \\
Gender & Male & 89 & $48.0 \%$ \\
& Female & 86 & $52.0 \%$ \\
\hline Age & 15 years & 38 & $21.7 \%$ \\
& 16 years & 55 & $31.4 \%$ \\
& 17 years & 50 & $28.6 \%$ \\
& 18 years & 32 & $18.3 \%$ \\
\hline Total & & 175 & $100 \%$ \\
\hline
\end{tabular}

The technology challenge questionnaire was used as a research instrument. This instrument were built base on literature review based on technology challenge model among adolescent in Malaysia (Malaysian Ministry of Youth and Sports, 2017). This instrument was review by three experts consisting of psychology fields, psychometric fields and language fields. The four-point likert scale is used on a scale of 1 (very disagreeable) to scale 4 (strongly agree). Neutral points are not used because they will only cause respondents to tend to choose neutral points as answers (Lucian, 2016) and will cause bias (Tsang, 2012). This instrument contains two sections, Part A contains a technological challenge item consisting of six dimensions of technology challenge and Part $B$ is the student's demographic information. Data were analyzed using Winstep 3.73 program. This program is ideal for analyzing and determining the hardest challenge items to the easiest. 
INTERNATIONAL JOURNAL OF ACADEMIC RESEARCH IN BUSINESS AND SOCIAL SCIENCES

Vol. 9, No. 6, June, 2019, E-ISSN: 2222-6990 (C) 2019 HRMARS

\section{Finding and Discussion}

Reliability Index and Separation Index of Technology Challenge Items

The reliability index refers to the consistency of the response given by the sampel. While the individual separation index indicates the level of capability identified in the sample group and the item separation index indicates the isolation of item difficulty level (Boone \& Noltemeyer, 2017). In this study the individual reliability index is 0.92 , while the item reliability index is 0.95 . Reliability index value greater than 0.8 is strong and acceptable (Bond \& Fox, 2015). For item separation index is 4.31 and individual separation index is 3.37. Individual separation index and item separation indez exceeding two are good (Linacre, 2018). High values for the reliability index and separation index indicate good measurement quality.

\section{Measurement of Technology Challenge Items}

Two main key assumptions that need to be met before analyzing the item using Rasch Model is the items fit (MNSQ) and the items must be unidimensional. The mean square value (MNSQ) for infit and oufit is 0.6 to 1.4 longits (Bond \& Fox, 2015). Finding two items that are 'addicted to playing games online' show MNSQ infit 1.95 and MNSQ outfit 1.94 values. While items 'spend more than five hours a day on social media' show MNSQ 1.61 and MNSQ outfit 1.64. This value indicates the item is does not fit the model. Hence, researchers need to make improvements or drop the item. To qualify both Rasch's model, Principal Component Analysis (PCA) shows the unexplained variance in $1^{\text {st }}$ construct value is $5.4 \%$ and meets the unidimensional requirement of not more than $20 \%$ (Cho et al., 2015). Once both of the main requirements of the Rasch Model are fulfilled, the next analysis is to measure the difficulty of the item. A total of 76 items from six dimensions of technology challenge have been measured. However, this study only shows 40 items indicating difficulty levels based on logistics more than 0.04. Table 2 shows the hierarchy of item difficulties (logits) and item fit (MNSQ). 
Table 2

\section{Hierarchy Level of Item Difficulties (logits) and Item Fit (MNSQ)}

\begin{tabular}{|c|c|c|c|c|c|}
\hline No. & Item & $\begin{array}{l}\text { Measurement } \\
\text { (Logits) }\end{array}$ & $\begin{array}{l}\text { Model } \\
\text { SE }\end{array}$ & $\begin{array}{c}\text { Infit } \\
\text { MNSQ }\end{array}$ & $\begin{array}{l}\text { Outfit } \\
\text { MNSQ }\end{array}$ \\
\hline 1 & Worried to make mistakes & 1.24 & 0.10 & 1.06 & 1.09 \\
\hline 2 & Feeling inferior when the ideas is rejected & 0.96 & 0.10 & 1.14 & 1.17 \\
\hline 3 & $\begin{array}{r}\text { Comfortably communicate on social media rather than meet } \\
\text { directly }\end{array}$ & 0.85 & 0.10 & 1.31 & 1.33 \\
\hline 4 & Difficult to identify valid source of information & 0.82 & 0.10 & 0.84 & 0.87 \\
\hline 5 & Likes to chat on social media & 0.65 & 0.10 & 1.01 & 1.01 \\
\hline 6 & $\begin{array}{r}\text { Do not know how to use science mathematic to create } \\
\text { useful products }\end{array}$ & 0.60 & 0.10 & 1.10 & 1.10 \\
\hline 7 & Mathematic makes me confused & 0.60 & 0.10 & 0.81 & 0.81 \\
\hline 8 & Addicted to playing games online & 0.54 & 0.10 & 1.96 & 1.95 \\
\hline 9 & Difficult to finding solutions to complex problems & 0.53 & 0.10 & 0.83 & 0.85 \\
\hline 10 & $\begin{array}{r}\text { Difficult to organize the flow of information from various } \\
\text { sources }\end{array}$ & 0.52 & 0.10 & 0.92 & 0.94 \\
\hline 11 & Not interested in construction & 0.50 & 0.10 & 0.88 & 0.89 \\
\hline 12 & Do not know how to convey new ideas well & 0.48 & 0.10 & 0.88 & 0.88 \\
\hline 13 & Spend more than five hours a day on social media & 0.48 & 0.10 & 1.62 & 1.63 \\
\hline 14 & Not interested to know how a machine work & 0.48 & 0.10 & 0.58 & 0.59 \\
\hline 15 & Take a long time to find information & 0.45 & 0.10 & 0.98 & 1.00 \\
\hline 16 & Dislike repairing damaged tools & 0.45 & 0.10 & 0.94 & 0.94 \\
\hline 17 & $\begin{array}{l}\text { Prefer to silence in the discussion to solve } \\
\text { problem }\end{array}$ & 0.40 & 0.10 & 1.12 & 1.14 \\
\hline 18 & $\begin{array}{r}\text { Prefer to make decision based on information from the } \\
\text { internet }\end{array}$ & 0.37 & 0.10 & 0.71 & 0.72 \\
\hline 19 & $\begin{array}{r}\text { Do not know the correct channels to make complaints if } \\
\text { bullied on social media }\end{array}$ & 0.36 & 0.10 & 1.34 & 1.34 \\
\hline 20 & Do not like to answer mathematic test & 0.24 & 0.10 & 0.83 & 0.83 \\
\hline 21 & Unable to give ideas spontaneously & 0.24 & 0.10 & 0.89 & 0.89 \\
\hline 22 & Do not know how to assess information & 0.23 & 0.10 & 0.69 & 0.70 \\
\hline 23 & $\begin{array}{l}\text { Puts high trust on information from the } \\
\text { internet compared to other sources such as books, } \\
\text { magazines and so on }\end{array}$ & 0.21 & 0.10 & 1.01 & 1.01 \\
\hline 24 & There is no good strategy to find information accurately & 0.20 & 0.10 & 0.82 & 0.83 \\
\hline 25 & Feel nervous when thinking about science & 0.18 & 0.10 & 0.79 & 0.79 \\
\hline 26 & Do not know how to combine ideas in solving problems & 0.17 & 0.10 & 0.64 & 0.64 \\
\hline 27 & $\begin{array}{r}\text { Difficult to use creative creation techniques such as } \\
\text { brainstorming }\end{array}$ & 0.16 & 0.10 & 0.65 & 0.67 \\
\hline 28 & Likes things that are easiest than challenging & 0.16 & 0.10 & 1.09 & 1.08 \\
\hline 29 & $\begin{array}{r}\text { Not fond of using media such as chat rooms to discuss } \\
\text { related to education }\end{array}$ & 0.16 & 0.10 & 1.16 & 1.15 \\
\hline 30 & Not interested in careers science related & 0.15 & 0.10 & 1.17 & 1.16 \\
\hline 31 & Difficult to test idea & 0.14 & 0.10 & 0.63 & 0.64 \\
\hline 32 & Not comfortable in science class & 0.14 & 0.10 & 0.93 & 0.92 \\
\hline 33 & It's hard to connect new information into & 0.12 & 0.10 & 0.56 & 0.56 \\
\hline 34 & It's hard to generate idea for solving a problem & 0.10 & 0.10 & 0.46 & 0.46 \\
\hline
\end{tabular}


INTERNATIONAL JOURNAL OF ACADEMIC RESEARCH IN BUSINESS AND SOCIAL SCIENCES

Vol. 9, No. 6, June, 2019, E-ISSN: 2222-6990 @ 2019 HRMARS

\begin{tabular}{|c|c|c|c|c|c|}
\hline 35 & Did violated the rules while on social media sites & 0.08 & 0.10 & 1.36 & 1.47 \\
\hline 36 & $\begin{array}{r}\text { Easily believe the information spread through electronic } \\
\text { media }\end{array}$ & 0.07 & 0.10 & 0.96 & 0.96 \\
\hline 37 & Bravely to meet up with friends rather than social media & 0.07 & 0.10 & 1.35 & 1.37 \\
\hline 38 & Not proficient to interpret the information received & 0.05 & 0.10 & 0.72 & 0.73 \\
\hline 39 & Difficult to analyze ideas & 0.04 & 0.10 & 0.47 & 0.47 \\
\hline 40 & Learning mathematic makes me feel worried & 0.04 & 0.10 & 0.82 & 0.84 \\
\hline
\end{tabular}

This study will only discuss the 10 items that most challenge the adolescent. 'Worried to make mistakes' (1.25 logits), 'feel inferior when the ideas is rejected' (0.96 logits) and 'difficult to finding solutions to complex problems' (0.53 logits) is a challenge in the dimension of creativity and innovation. Trilling \& Fadel (2009) stressed that patience, openness to new ideas, high trust and learning from mistakes and failure are a natural process that can shape itself to be more creative and innovative. The finding of Shi et al. (2016) has proven that openness to experience has a significant relationship between intellectual intelligence and creative thinking. Thus, adolescent who are worried to make mistakes, always feel inferior and impatient will prevent them from continuing to develop their potential for more creative and innovative in facing for more challenging future.

'Comfortably communicating on social media rather than meet directly' ( 0.85 logits), 'likes to chat on social media' ( 0.65 logits) and 'addicted to playing games online' ( 0.54 logits) show challenges in social media dimensions. This finding is in line with Malaysian Communication and Multimedia Commission study (2017) which found $96.3 \%$ of Malaysian using internet for the purpose of communicating through texts such as Whatsapp, Instagram, Facebook, Wechat and Twitter. Social media is a social network that allows interaction to occur regardless of age limit (Mustafa, 2016). Lengacher (2015) states that social relationship will be affected when using the phone while facing face-to-face with others. In addition, 'addicted to online games' is also a challenge for adolescent. Uncontrolled online games show significant relationship with psychological problem such as stress and self-isolation or solitude (Ko, 2014). Players via the internet show that $41.6 \%$ of users (Malaysian Communication and Multimedia Commission, 2017). Excessive use of the internet, especially among adolescent will affected social relations with peers (Topaloglu, 2015).

Challenges in information and communication technology (ICT) dimensions are 'difficult to identify valid source of information' ( 0.82 logits) and 'difficult to organize the flow of information from various sources ( 0.52 logits). In mastering ICT literacy, adolescent must be proficient in using digital technology, communication tools, accessing networks, managing, integrating, evaluating and delivering useful information for the community (The International ICT Literacy Panel, 2002; Trilling \& Fadel, 2009). Adolescent need to have good ICT literacy so they cannot be easily deceived by various information from electronic media (Ruddock, 2013). Low of ICT literacy will cause adolescent to lag behind and unable to compete globally. The widespread use of ICT in life requires adolescent more proficient in all aspects to make them more skilled and have a high level of competitiveness.

Furthermore, the challenges in science and technology dimensions are 'Mathematic makes me confused' ( 0.60 logits) and 'do not know how to use science and mathematic to create useful 
products' (0.60 logits). The study by Schnepper \& Mccoy (2017) found that misconceptions in mathematics were due to misinterpretation of the information. The discrepancy among students is due to the less effective method of teaching (Bunyamin, 2015). This statement is supported by Salahudin et al. (2015) which state that the effectiveness of teaching methods can enhance the students ability to master certain skills. Teachers need to adapt good teaching methods to make the learning environment more attractive (Olsen \& Chernobilsky, 2016). Positive reinforcement factor is also very important in encouraging students to stay motivated starting from lower level (Noor \& Zakaria, 2018). Highly motivated students are less likely to do negative things such as skipping school (Akomolafe et al., 2013).

Science is knowledge that can be proven by its authenticity through research and guidance. Technology is derived from a combination of science and other systematic system in producing something that facilitates universal humanity (Ibrahim et al., 2018). Hence, today's science, technology, engineering and mathematical (STEM) learning has been emphasized in all world education systems (Dugger, 2010). Integration of STEM disciplines allows problems to be thoroughly assessed from a different perspective (Tekerek, 2016). This is because problems or questions can be answered through scientific engagements and problems related to engineering design can be evaluated during the design stage (Kennedy \& Odell, 2014). Adolescent who are able to master STEM can make the country more productive. Hence, adolescent need to know how to combine science and mathematics or other knowledge to produce something useful for the community use.

These challenges are also discussed thoroughly in the domain of Technology Challenges. Measurement of difficulty based on six dimensional technology challenges is shown in Table 3. However, only three main dimensions are discussed.

Table 3

Average Measurement of Difficulties (logits) Based On Six Dimension Technology Challenges

\begin{tabular}{clc}
\hline No. & \multicolumn{1}{c}{ Dimension } & $\begin{array}{c}\text { Average Measurement } \\
\text { of Difficulties } \\
\text { (Logits) }\end{array}$ \\
\hline 1 & Creativity and Innovation & 0.188 \\
3 & Information and Communication Technology(ICT) & 0.174 \\
2 & Science and Technology & 0.170 \\
4 & Ethics and Cyber Security & -0.139 \\
5 & Digital @ Social Media & -0.183 \\
6 & Cyber bullying & -0.516 \\
\hline
\end{tabular}

The findings show the dimensions of creativity and innovation are 0.188 logits. Creative is cognitive ability to produce something new and useful (Runco \& Jaeger, 2012). Creative attitude is a feature that allows creative thinking skills to emerge as an innovation (Kim, 2017). Creativity is not only 
closely related to intellectual but it can be nurtured through learning and training environments (Trilling \& Fadel, 2009). Jauk et al., (2014) proves that intellectual intelligence is not a factor in creativity. Previous study only discuss the relationship of creativity with intellectual intelligence (Benedek et al., 2014; Shi et al., 2016; 2017). But studies related to the challenges faced by adolescent to be more creative are not reviewed. The findings of this study found that internal factors such as fear and worry were a barrier to becoming more creative. Hence, adolescent should be given more support with self-development activities so that adolescent are more confident. An environment that promotes creative thinking needs to be set up to train adolescent to produce good ideas. Wu et al. (2014) proves that learning environment and cultural environment have a high impact on the development of creativity. Learning nowadays is no longer just based on facts but students are often exposed to high level thinking skills to solve a problematic situation (Bunyamin, 2016). This effort is aimed at training adolescent to be able to produce useful ideas and benefit for the country development.

Other than that, adolescent also face challenges in ICT dimensions of 0.174 logits and followed by challenges in science and technology dimensions of 0.170 logits. This finding is further reinforced by the finding of Malaysia of Science, Technology and Innovation (2017) study showing student enrollment in science technology and literature is 45.74:54.25. This shows that basic 60:40 in science and technology has yet to be achieved (Phang et al., 2012). In addition, student achievement in the Program for International Assessment (PISA) which measures the scientific literacy domain, mathematical literacy and reading literacy indicates that most students in Malaysia are at a moderate level of 410, 407 and 420 respectively (Ministry of Education, 2016). These statistic show students in Malaysia are still lagging behind countries like Singapore, Japan, Estonia, Finland and Canada. These five countries recorded the highest score in PISA 2015 (Organization for Economic Cooperation and Development, 2016). Most of the students in the country are at the top at five or six levels. Hence, it can be concluded that Malaysian students still have to work harder to reach the highest level. Overall, it can be concluded that the three dimensions in this technology challenge domain are closely related to each other. In mastering Science and Technology, adolescent should have knowledge and skill in ICT and have creativity and innovation. This is because in the 4IR era, almost daily activities are driven by ICT advancement (Fauzi, 2017). The stakeholder should take serious look at these challenges to prepare the adolescent to meet the challenges of the future. Malaysia's desire to become a developed nation will be achieved if the adolescent are formed with the right mold.

\section{Conclusion}

The results of this study summarize three main dimensions that challenge technology among adolescent. The most challenging dimensions of the era of transformation are science and technology, creativity and innovation as well as ICT. Thus, balanced self-development among adolescent should be given priority in forming self-esteem and endurance to meet global challenges (Matore \& Khairani, 2013). This is because in this 4IR era technology is benchmark for development of a country. Technology begins to take over the work done by humans, if it is managed successfully, will improve the quality of human life. If fails to manage well, it will invite a risk to future gaps in skill 
(Schwab, 2018). ICT skills and creativity and innovation are key factor in mastering technology. Hence, it can be concluded that this three dimensions are interdependent in the face of technological challenges. The stakeholder should take of this dimension to produce a world class adolescent. Implications of this study require stakeholder such as school organizations or educational ministry to identify the challenges faced by adolescent. Adolescent development is important because at this stage they are undergoing complex developments (United Nations International Children's Emergency Fund, 2017). Special programs need to be scrutinized for the purpose of developing and motivating adolescent to continue to face challenging challenges. Education programs should be based on ICT to improve student skills in this technology era. The $21^{\text {st }}$ century skills need to be applied in the education system so that students can adapt and then address the increasingly fierce challenges. This study also contributes to the development of universal human capital to continue to face challenge in this global world.

\section{Acknowledgment}

Thank you to the Ministry of Education Malaysia and all the schools involved in this research study. Also thank you to all individuals who name cannot be mentioned here one by one, who have cooperated during this research. This research can't complete without the help from various parties in the form of guidance, required data, suggestions and motivation.

\section{Corresponding Author}

Salwana Bt Mahamud

Faculty of Education

National University of Malaysia (UKM)

Email: salwanamahamud@gmail.com

\section{References}

Akomolafe, M. J., Ogunmakin, A. O. \& Fasooto, G. M. (2013). The role of academic self-efficacy, academic motivation and academic self- concept in predicting secondary school students' academic performance. Journal of Educational and Social Research 3(May): 335-342. doi:10.5901/jesr.2013.v3n2p335

Anderson, E. L., Steen, E. \& Stavropoulos, V. (2017). Internet use and problematic internet use: a systematic review of longitudinal research trends in adolescence and emergent adulthood. International Journal of Adolescence and Youth 22(4): 430-454. doi:10.1080/02673843.2016.1227716

Benedek, M., Jauk, E., Sommer, M., Arendasy, M. \& Neubauer, A. C. (2014). Intelligence, creativity, and cognitive control: The common and differential involvement of executive functions in intelligence and creativity. Intelligence 46: 73-83. doi:10.1016/j.intell.2014.05.007

Bond, T. G., \& Fox, C. M. (2015). Applying the Rasch Model: Fundamental measurement in the human sciences, Third Edition . New York: Routledge.

Boone, W. J. \& Noltemeyer, A. (2017). Rasch analysis: A primer for school psychology researchers and practitioners. Cogent Education 25: 1-13. doi:10.1080/2331186X.2017.1416898 
INTERNATIONAL JOURNAL OF ACADEMIC RESEARCH IN BUSINESS AND SOCIAL SCIENCES

Vol. 9, No. 6, June, 2019, E-ISSN: 2222-6990 @ 2019 HRMARS

Bunyamin, M. A. H. (2015). Pendidikan STEM Bersepadu : Perspektif global, perkembangan semasa di Malaysia, dan langkah ke hadapan. Buletin Persatuan Pendidikan Sains dan Matematik Johor 25(1),1-6

Bunyamin, M. A. H. (2016). Kemahiran berfikir aras tinggi: Perspektif pedagogi kritikal dan budaya pendidikan Malaysia. Malaysian Journal of Higher Order Thinking Skills in Education, Vol. 1.

Ceobanu, C. \& Boncu, S. (2014). The challenges of the mobile technology in the young adult education. Procedia - Social and Behavioral Sciences 142: 647-652. doi:10.1016/j.sbspro.2014.07.680

Cho, S., Drasgow, F. \& Cao, M. (2015). An investigation of emotional intelligence measures using item response theory. Psychological Assessment 27(4): 1241-1252. doi:10.1037/pas0000132

Cohen, L., Manion, L., \& Morrison, L. (2011). Research Methods in Education, Seven Edition. USA and Canada:Routledge.

Creswell, J. W., \& Creawell, J. D. (2017). Research Design: Qualitative, Quantitative, and Mix Methods Approaches, Fifth Edition. United State of Amerika: Sage Publication Institute.

Deloitte Global, \& The Global Business Coalition for Education. (2018). Preparing tomorrow's workforce for the Fourth Industrial Revolution For business: A framework for action. United State.

Dugger, W. E. (2010). Evolution of STEM in the United States. 6th Biennial International Conference on Technology Education Research in Australia.

Fauzi, N. (2017). Penggunaan media sosial dalam dunia tanpa sempadan: Suatu kebaikan atau keburukan?

George, M. J., \& Odger, C. L. (2015). Seven fears and the science of how mobile technologies may be influencing adolescents in the digital age. Perspect Psychol Sci. 10(6): 832-851. doi:10.1177/1745691615596788.

Ghasemi, V., Rabiei, K., Davoodi, S. \& Rabiei, H. (2017). Mobile internet usage among adolescents and young adults in Iran: A Sociological survey. Journal of History Culture and Art Research 6(1): 863. doi:10.7596/taksad.v6i1.785

Giedd, J. N. (2012). The digital revolution and adolescent brain evolution. Journal Adolescent Health 51(2): 101-105. doi:10.1016/j.jadohealth.2012.06.002.

Guan, S. S. A. \& Subrahmanyam, K. (2009). Youth internet use: risks and opportunities. Current Opinion in Psychiatry 22(4).

Ibrahim, M. I., Nazri, F. I., Basiron, B., Baharuddin, A., Bidang, M., Persepsi, K. \& Bentong, S. I. (2018). Islam serta pembentukan sains dan teknologi. Prosiding Seminar Tamadun Islam UTM, 1-2.

Ismail, A. M., Mohd Zain, M. Z. \& Abdul Khadir, M.N. (2012). Broadcasting media impact to Malay students behavior in Malaysia. Journal of Applied Sciences Research, 8(5): 2596-260

Jauk, E., Benedek M., \& Neubauer. A. C. (2014). The road to creative achivement: A latent variable Model of Ability and personality predictors. European Journal of Personality 28: 95-105. doi:10.1002/per.1941

Kennedy, T. J. \& Odell, M. R. L. (2014). Engaging students in STEM education. Science Education International Journal 25(3): 246-258.

Kim, K. H. (2017). The Torrance Test of creative thingking-figural or verbal: Which one should we use?. Creativity Journal 4(2). doi:10.1515/ctra-2017-0015 
INTERNATIONAL JOURNAL OF ACADEMIC RESEARCH IN BUSINESS AND SOCIAL SCIENCES

Vol. 9, No. 6, June, 2019, E-ISSN: 2222-6990 @ 2019 HRMARS

Ko, C. H. (2014). Internet gaming disorder. Current Addict Rep 1: 177-185. doi:10.1007/978-3-31969638-6_9

Lengacher, L. (2015). Mobile Technology: its effect on face-to-face communication and interpersonal interaction. Undergraduate Research Journal for the Human Sciences 14.

Linacre, J. M. (2018). A User's guide to WINSTEPS Rasch-Model computer program: Program manual 4.2.0. Chicago: MESA Press.

Lucian, R. (2016). Rethinking the use of likert scale: Tradition or technical choice. Brazillian Journal of Marketing opinion, and Media Research 18: 13-30.

Malaysian Institute for Youth Research (Institut Penyelidikan Pembangunan Belia Malaysia). (2017). Buli siber dalam kalangan belia Malaysia.

Malaysian Ministry of Youth and Sports. (2017). Dasar Belia Malaysia. Retrieved from http://www.kbs.gov.my/my/dasar-belia-malaysia

Malaysian Ministry Of Education. (2016). PISA 2015- Programme For International Student Assessment.

Pauzi, M. (2017). Revolusi Perindustrian 4.0 satu pengenalan. PAMI Resourse| Empayar Revolusi Buku.

Matore, M. E. E. \& Khairani, A. Z. (2013). Cabaran permasalahan pelajar Politeknik menggunakan Model Rasch. 2nd International Seminar on Quality and Affordable Education (Isqae 2013): 337347.

Ministry of Science, Technology and Innovation. (2017). Malaysian Science, Technology and Innovation Indicators Report 2016.

Mohd Noor, M. S., \& Megat Zakaria, M. A. Z. (2018). Tinjauan motivasi, sikap dan peningkatan prestasi murid sekolah rendah melalui penggunaan halaman celik akal (VLE). Sains Humanika 10(3): 713.

Malaysia Computer Emergency Response Team. (2017). Report incidents based on general incident classification statistic 2017. Retrieved from https://www.mycert.org.my/statistics/2017.php

Nordin, F. L. \& Othman, M. Z. (2016). Faktor-faktor yang mempengaruhi penyalahgunaan ICT di kalangan pelajar di UUM Sintok Kedah Darul Aman. Symposium of Technology Management \& Logistic 10(April): 36-53.

Maya, N. (2015). Fenomena cyberbullying di kalangan pelajar. Jurnal Ilmu Sosial dan Ilmu Politik 4(3): 443-450.

Olsen, A. K. \& Chernobilsky, E. (2016). The effects of technology on academic motivation and achievement in a middle school mathematics classroom. NERA Conference Prosiding.

Phang, F. A., Abu, M. S., Ali, M. B. \& Salleh, S. (2012). Faktor penyumbang kepada kemerosotan penyertaan pelajar dalam aliran sains: satu analisis sorotan tesis. Sains Humanika 36(3) doi:10.14221/ajte.2011v36n3.2

Ramli, R. (2011). The internet, its social and ethical problem to the young and how curriculum can address the issue. World Academy of Science, engineering and Technology 59(125): 645-648.

Runco, M. \& Jaeger, G. (2012). The standard definition of creativity. Creativity Research Journal, Vol. 24. doi:10.1080/10400419.2012.650092

Salehudin N. N., Hassan, N. H., \& Hamid, A. N. A. (2015). Matematik dan kemahiran abad ke-21: perspektif pelajar. Jurnal Pendidikan Matematik 3(1): 24-36. 
Schnepper, L. C., \& Mccoy, L. P. (2017). Analysis of misconceptions in High School Mathematics. An Online Journal For Teacher Research. 15(1).

Schwab, K. (2016). The Four Industrial Revolution. World Economic Forum. Retrieved from http://gen.lib.rus.ec/book/index.php?md5=B9183A3C2454F510580B57BE0E5C22B3

Schwab, K.(2018). Insight Report The Future of Jobs Report. Geneva Switzerland.

Shi, B., Dai, D. Y. \& Lu, Y. (2016). Openness to experience as a moderator of the relationship between intelligence and creative thinking: A study of chinese children in urban and rural areas. Frontiers in Psychology 7: 1-10. doi:10.3389/fpsyg.2016.00641

Shi, B., Wang, L., Yang, J., Zhang, M., Xu, L. \& Hoff, E. V. (2017). Relationship between divergent thinking and Intelligence : an empirical study of the threshold hypothesis with Chinese children. Educational Psychology 8: 1-9. doi:10.3389/fpsyg.2017.00254

Singh, H. K. B. (2013). Buli Siber. Portal MyHealth Kementerian Kesihatan Malaysia. http://www.myhealth.gov.my/cyberbullying/

Malaysian Communication and Multimedia Commision. (2017). Internet User Survey 2017. Cyberjaya, Selangor.

Tekerek, M. (2016). Ethical reasoning in STEM disciplines. Journal of Education and Practice 7(32): $182-188$.

The International ICT Literacy Panel. (2002). Digital transformation: A framework for ICT literacy. Princeton, New Jersey.

Tjandrawinata, R. R. (2016). Industri 4.0: revolusi industri abad ini dan pengaruhnya pada bidang kesehatan dan bioteknologi. Dexa Laboratories of Biomolecular Sciences

Topaloglu, A. O., \& Topaloglu, M. (2015). The study of computer technology and information systems students' problematic internet use levels and predictiveness with the regard to various variables. Procedia - Social and Behavioral Sciences 182: 637-644. doi:10.1016/j.sbspro.2015.04.800

Trilling, B., \& Fadel, C. (2009). 21st century skills learning for life in our times. (U. State, Ed.). John Wiley \& Sons, Inc.

United Nations Children's Fund. (2017). The adolescent brain: A second window of opportunity. New York: Courtesy Ronald Feldman Fine Arts.

Utami, Y. C. (2014). Cyberbulliying di kalangan remaja. Universitas Airlangga 3(3): 1-10.

Wu, H. Y.,Wu, H. S., Chen I. S. \& Chen H.C. (2014). Exploring the critical influential factors of creativity for college students: A multiple criteria decision-making approach. Thinking Skills and Creativity 11: $1-21$. 